- DOI: 10.31866/2410-1311.36.2020.221046 Удк 008:[719:911.375

\title{
- КУЛЬТУРНА ПАМ’ЯТЬ МІСТ
}

\section{- Отрішко Марина Анатоліївна}

Здобувач, ORCID: 0000-0001-7944-5085, e-mail: m_14@ukr.net,

Київський національний університет культури і мистецтв, вул. Є. Коновальця, 36, Київ, Україна, 01133

\section{- Для цитування:}

Отрішко, М.А. (2020). Культурна пам'ять міст. Питання культурології, (36), 60-68. doi: https://doi. org/10.31866/2410-1311.36.2020.221046.

\section{- Анотація}

Мета статті - обґрунтування значущості культурної пам'яті як чинника культурного розвитку міст. Методологія дослідження базується на використанні таких методів: пошуковий, порівняльний, аналіз і синтез, що дозволило виявити трансформацію тлумачення культурної пам'яті у різних часових проміжках. Наукова новизна роботи полягає в тому, що в ній вперше проаналізовано еволюцію розуміння громадськістю поняття «культурна пам'ять». В статті доведено, що «пам'ять», «мистецтво пам'яті», «культурна пам'ять» $є$ об'єктом зацікавлення у кожній з культурних епох. Античні мислителі $є$ першовідкривачами культури пам'яті. Проте, поняття «культурна пам'ять» з'являється у науковому обігу лише наприкінці XX ст. у дослідженнях Я. Ассмана. Під культурною пам'яттю розуміють сферу буття; простір у поєднанні з культурною інфраструктурою; середовище збереження системи культурних цінностей, що наявні у публічному просторі. Висновки. Виявлено, що культурна пам'ять має вагомий вплив на побудову ідентичності і громадян, і міста. Завдяки збереженню і «прочитанню» культурної пам'яті у просторі міста відбувається зв'язок суспільства з минулим, усвідомлення цінностей, моделей поведінки громадськості у різних історичних періодах. Обґрунтовано, що культурна пам'ять є невід'ємною складовою міського простору. Відіграючи роль «діалогу» між минулим і сьогоденням, культурна пам'ять відображає цінності суспільства за допомогою «культурного коду міста». Найбільш змістовно культурна пам'ять виявляється у культурі меморіалізації: пам'ятниках, меморіальних комплексах, пам'ятних спорудах, надписах, демонструючи світоглядні особливості певного історичного періоду. Однак, процес глобалізації має негативний вплив на культурну пам'ять у місті, спричиняючи асиміляцію культурних цінностей. Акцентування на збереженні, примноженні і просуванні об'єктів культурної пам'яті у містах є значущим та сприятиме осмисленню власної ідентичності і вдосконаленню соціокультурного розвитку територій.

Ключові слова: пам'ять; культурна пам'ять; мистецтво пам'яті; публічний простір; місто 


\section{Вступ}

Кожне місто має власну ідентичність, яка фрормується на основі культурної пам'яті та візуально виявляється у публічному просторі міста завдяки пам'ятникам, меморіальним дошкам, скульптурам, ландшафтним об'єктам, паркам, прогулянковим доріжкам тощо, які мають сакральне смислове навантаження. Проблематика культурної пам'яті $€$ актуальною у кожній з епох розвитку людства та відображає соціально-культурний розвиток міст.

Наукова новизна роботи полягає в тому, що в ній вперше проаналізовано еволюцію розуміння громадськістю понять «пам'ять», «культурна пам'ять». Культурна пам'ять $€$ важливим чинником вираження ідентичності міста. Бувши об'єктом трансформації, рушієм демократичних змін у суспільстві, вона допомагає фрормуванню, збереженню, трансляції і розвитку культурних норм, цінностей, знань і смислів, інтеграції й соціальній консолідації, а також має потужні ресурси в умовах демократичної та правової держави (Вербицька, 2018, с. 21). У суспільстві пам'ять фрормує нові соціальні межі дій та вчинків, що є підґрунтям утворення свідомої особистості, яка здатна до усвідомленого вибору і прийняття рішення (Вербицька, 2018, с. 21). «Культурна пам'ять ґрунтується на системі цінностей, які через культуру, місця пам'яті визначають спрямування ідентичності особистості» (Вербицька, 2018, с. 20).

На даному етапі соціально-культурного розвитку культурна пам'ять $є$ об'єктом зацікавлення науковців. У статті проаналізовані основоположні праці античних мислителів Цицерона - трактат «Про оратора», Квінтиліана «Риторичні настанови», які $\epsilon$ підґрунтям зародження мистецтва пам'яті. Опрацьовані дослідження робочої групи «Археологія літературної комунікації», зокрема збірки «Лист і пам'ять», «Канон і цензура», «Мудрість», «Простору пам'ять. До конструювання культурного часу», що надали можливість з'ясувати сутність поняття «культурна пам'ять». Вивчені наукові доробки вітчизняних і закордонних дослідників із проблемної теми. Зокрема, наукову цінність становлять праці В. Вахштайна «Колективна пам'ять як ресурс концептуалізації публічних та приватних просторів в мегаполісі», П. Вербицької «Культурна пам'ять як чинник конструювання ідентичності в умовах трансформації українського суспільства», Р. Голика «Пам'ять культури на роздоріжжях науки: проблеми теорії. Україна модерна», де автори демонструють цінність культурної пам'яті й для громадян, і для міста загалом.

У публічному просторі розташовані об'єкти культури, які, комунікуючи із громадськістю, є провідними інформаторами історичних подій, культурної спадщини міста. Збереження і примноження культурної пам'яті наразі є актуальним. Втім, з урахуванням глобалізації, технологічного розвитку відбувається зміна культурних цінностей, що надалі стане поштовхом до знецінення культурної пам'яті сьогодення.

\section{- Мета статті}

Метою статті є обґрунтування значущості культурної пам'яті як чинника культурного розвитку сучасного міста. Методологія дослідження ґрунтується на використанні таких методів: пошуковий, порівняльний, аналіз і синтез, що доз- 
волило виявити трансформацію тлумачення культурної пам'яті у різних часових проміжках.

\section{- Виклад матеріалу дослідження}

У зв'язку з процесом глобалізації прослідковуються зміни у всіх сфрерах життя, особливо культурній. Саме глобалізація сприяла трансформації змісту культурної пам'яті, зокрема стиранню меж між існуючими видами пам'яті. Останнім часом можемо спостерігати процеси видозміни сутності культурної пам'яті сприйняття її не як традиції (Толкачева, 2019, с. 3). Суспільство, яке утворює культурну пам'ять про минуле, продукує свої уявні образи та власну ідентичність крізь зміну поколінь, однак робить це по-різному (Ассман, 2004, с. 17).

Останні десятиліття привернули цікавість соціуму до пам'яті та спогадів такі чинники, як: поява електронних засобів збереження інформації, зокрема штучної пам'яті в період епохи культурної революції; розуміння культурної традиції як посткультури, де події, які завершилися, продовжують існувати як предмет спогадів і коментуючої обробки; загроза зникнення живих спогадів, які утворюються фрормами культурної пам'яті про минуле (Ассман, 2004, с. 11).

Першовідкривачами культури пам'яті, означуваної як мистецтво пам'яті були античні мислителі. Цицерон у трактаті «Про оратора» аналізує історію поета Сімоніда, який винайшов мистецтво пам'яті та стверджує, що саме запам'ятовування місць допомогло Сімоніду згадати й розпізнати гостей. Тобто, хороша пам'ять залежить від впорядкованого викладу, а для хорошого запам'ятовування варто вибрати місця, подумки сформувати образи речей, які варто запам'ятати, розмістити образи на місцях. Порядок місць зберігатиме порядок речей, а образи будуть відображати самі речі (Цицерон, 1972, с. 351-354). Квінтиліан (Квинтилиан, 1834) також згадує у своїх настановах оратору пам'ять, зазначаючи, що вона є ознакою розуму, а також допомогою, яка може полегшити старання учнів (с. 13).

С. Шипілов (Шипилов, 2018) зазначає, що у добу Середньовіччя культурна пам'ять проявляється у європейських хроніках, зокрема в контексті духовної культури, відображаючи різностороннє духовне життя тогочасного суспільства, а саме: систему світоглядних ідей, оцінку дій у соціумі, опозицію «свій - чужий» та інше (с. 288). У хроніці не лише фріксуються події, а й подається трактування, інтерпретація у межах тієї соціокультури, в якій і була створена хроніка (Шипилов, 2018, с. 291).

А. Гуревич (1990) доводить, що у добу Середньовіччя культурна пам'ять також фріксувалася у літературному жанрі - прикладах (exempla), що мають пізнавальну цінність (с. 135). Приклади є «атомарними», найменшими одиницями свідомості, яка ще не організувала свій матеріал в культурні творіння (Гуревич, 1990, с. 147-148). Це не культура у її закінченому вигляді, а елементи, з яких вона будувалася. Мотиви, що були розроблені в прикладах, активно використовувалися у мистецтві (книжкова мініатюра або мала скульптура) на капітелях церков та соборів. Ці зародки різних фрорм культури, «атоми» свідомості постійно були присутніми в пам'яті культури і відображаються в різних її проявах, піддаючись різного роду перетворенням (Гуревич, 1990, с. 148). 
Приклади висуваються на основний план відмінно від інших категорій літератури XIII ст. як джерело, під час безпосереднього вивчення яких можна чітко з'ясувати для себе відношення різних шарів і рівнів середньовічної культури (Гуревич, 1990).

І. Євлампієв (Евлампиев, 2016) доводить, що у добу Відродження об'єктом культурної пам'яті $€$ архітектурні споруди, витвори образотворчого мистецтва, літератури, наукові та фрілософрські трактати, музеї. Музей усвідомлюється «об’єктивованою культурною пам'яттю європейської цивілізації, динамізмом культури» (с. 106).

Поширення явища інформатизації сприяє зміні культурних цінностей. Так, поява новітніх засобів комунікації провокує уніфікацію міста та виявляється у розмиванні культурного коду міста і його унікальності; руйнуванні внутрішньої єдності міського населення (Кравченко, 2019, с. 4). О. Кравченко, зазначає, що у період постіндустріальної доби основною умовою міського розвитку є його комунікаційний потенціал, який є чинником формування культурних трансформацій. Місто існує в декількох вимірах: окрім матеріальної культури, втіленої в будівлях, дорогах, технічних засобах комунікації, місто живе в історичній пам'яті, символах, образах, асоціаціях, які відображені у літературі, витворах мистецтва тощо (Кравченко, 2019, с. 2-3). На думку дослідниці, важливим є розуміння поняття «культурного коду міста» - сукупності історично сформованих матеріальних та духовних цінностей, природних явищ і артефактів, на основі яких формується цілісний образ певного конкретного міста (Кравченко, 2019, с. 4). Кравченко (2019) стверджує, що «глобалізація негативно впливає на розвиток міст, провокуючи розмивання культурної унікальності» (с. 19).

Культурна пам'ять містить у собі культуру меморіалізації, яка безпосередньо пов'язана з проблемою культурної ідентифікації (Святославский, 2011, с. 3). Культура пам'яті уміщує в собі комеморацію, що фрормується із сукупності соціокультурних мнемічних практик, які утворюють комеморативні знаки. Під комеморацією розуміється усвідомлений соціальний акт передачі інформації значущої моральної, естетичної, світоглядної, технологічної шляхом увічнення облич, подій (уведення образів минулого у пласт сучасної культури). Так, завдяки дослідженню об'єктів меморіалізації є можливість відображення особливостей національного менталітету зокрема складових національної культури (Святославский, 2011, с. 4). Предметом дослідження науковця виявилися архітектурно-скульптурні меморіальні споруди, пам'ятні знаки, надписи, престоли, храми, дзвіниці, найменування різноманітних встановлень, зокрема меморіальна топоніміка, некрополі, музеї, меморіальні комплекси і т.п. (Святославский, 2011, с. 4). О. Святославський (2011) зазначає, що інформацію, яку хотіла передати певна культура у майбутнє, закладалася у категорію пам'ятників, які встановлювалися з метою навмисного увічнення. Меморіальна культура («листи в майбутнє»), бувши концентратом світоглядних особливостей культури загалом, суттєво впливає на формування світогляду та моральних цінностей (с. 4).

Процеси індустріалізації та урбанізації Західної Європи сприяли підвищенню зацікавленості проблемою пам'яті. Пам'ять розуміють як «процес споживан- 
ня образів минулого суспільством»; інтерсуб'єктивний (змінний) феномен (Гайдай, 2018, с. 10-20). Як основоположна категорія людської культури, пам'ять досліджується на таких рівнях: індивідуальному і колективному. Важливим є вивчення пам'яті як семантичного поля, у центрі тяжіння якого опиняються асоціативно пов'язані категорії мислення й мовлення (Голик, 2017, с. 1). Пам'ять - це конструювання образу міста, який, як наслідок починає впливати на його повсякденне життя (Вахштайн, 2018, с. 4).

Поняття культурної пам'яті з'являється у науковому обігу наприкінці XX ст. і знаходить відображення у матеріалі робочої групи «Археологія літературної комунікації» та надалі відстежується у збірках «Лист і пам'ять» (1983), «Канон і цензура» (1987), «Мудрість» (1991), «Простору пам'ять. До конструювання культурного часу» (1991) (Ассман, 2004, с. 12). У цих збірках культурна пам'ять означається як простір, у якому відбивається культурна сфера, інфраструктура у часовій приналежності (Ассман, 2004, с. 19-20).

Під поняттям «культурна пам'ять» розуміють також і сфреру буття, що формує ціннісно-смисловий світ соціуму (Толкачева, 2019, с. 3), і як «відтворення соціокультурного цілого та його здатність зберігати у своєму актуальному сьогоденні минуле», іманентна властивість соціокультурного організму (суспільства), що складається зі здатності зберігати себе у всіх своїх модифікаціях, відтворюючи умови свого власного існування на всіх етапах розвитку; атрибутивна характеристика суспільства (органічна система); фрілософське поняття (Рагозина, 2017, с. 12-17).

Культурна пам'ять у просторі міста сприяє зв'язку суспільства з минулим, усвідомленню цінностей громадськості конкретного часового проміжку, надає можливість досліджувати шляхи фрормування ідентичностей, культурної спадщини, цінностей та моделей поведінки людей у різних історичних періодах. У просторі сучасного міста практики і форми меморіалізації $є$ одним із найпоширеніших та важливих методів відновлення культурної пам'яті. Простір міста переповнений пам'яттю, яка $є$ інструментом його соціально-просторової організації та історичної спадковості.

\section{- Висновки}

Культурна пам'ять $€$ важливим чинником культурного розвитку міста. Залежно від трансформаційних змін протягом історичних періодів від Античності до сьогодення поняття «культурна пам'ять» набувало нових смислів: сфера буття; простір, що уміщує культурну інфрраструктуру; середовище збереження системи культурних цінностей, що проявляється у публічному просторі під виглядом міського тексту, зокрема скульптур, пам'ятників, меморіальних дощок, місць пам'яті, паркових територій. Під впливом глобалізації відбувається асиміляція культурних цінностей, що негативно впливає на збереження ідентичності публічних просторів міст. Привернення уваги до культурної спадщини $є$ важливим етапом на шляху до формування якісного соціокультурного розвитку територій сучасних міст, адже діалог між минулим і сьогоденням ідентифікує цінності й основні смисли, які покладені в основу попередніх культур. 


\section{- Список використаних джерел}

Ассман, Я. (2004). Культурная память. Письмо, память о прошлом и политическая идентичность в высоких культурах древности (М. М. Сокольская, Пер.). Языки славянской культуры.

Вахштайн, В. (2018). Коллективная память как ресурс концептуализации публичных и приватных пространств в мегаполисе. Взято 9 квітня, 2020, з https://cutt. ly/4hzowzv.

Вербицька, П. (2018). Культурна пам'ять як чинник конструювання ідентичності в умовах трансформації українського суспільства. Historical and Cultural Studies, 5(1), 15-22. http://science.Ipnu.ua/sites/default/files/journal-paper/2019/apr/16428/5.pdf.

Гайдай, О. (2018). Кам'яний гість. Ленін у центрі України (2-ге вид.). К.І.С.

Голик, Р. (2017, 14 серпня). Пам'ять культури на роздоріжжях науки: проблеми теорії. Україна Модерна. https://uamoderna.com/demontazh-pamyati/holyk-collectivememory.

Гуревич, А. (1990). Средневековый мир: культура безмолвствующего большинства. Искусство.

Евлампиев, И. И. (2016). Идея музея в контексте европейской модели культуры и ее постмодернистское отрицание. Международный журнал исследований культуры, 3(24). http://www.intelros.ru/pdf/Int_culture_researsh_mag/2016_03/ ijcr_3-24-2016_evlampiev\%20103-114.pdf.

Квинтилиан, М. Ф. (1834). Двенадцать книг риторических наставлений (А. Никольский, Пер., ч. 1). Императорская Российская Академия. http://ancientrome.ru/antlitr/t. htm?a=1295581698.

Кравченко, О. (2019). Культурні трансформації міста у постіндустріальну добу [Дисертація кандидата фрілософських наук, Національний авіаційний університет].

Рагозина, Т. (2017). Культурная память versus историческая память. Наука. Искусство. Культура, 3(15), 12-21.

Святославский, А. (2011). Среда обитания как среда памяти: к истории отечественной мемориальной культуры [Автореферат диссертации доктора культурологи, Московский педагогический государственный університет].

Толкачева, В. (2019). Трансформация содержания культурной памяти в виртуальном пространстве [Автореферат диссертации кандидата философских наук, Национальный исследовательский Томский политехнический университет].

Цицерон, М. Т. (1972). Три трактата об ораторском искусстве (Ф. А. Петровский, Пер., кн. 2). Наука.

Шипилов, С. (2018). Средневековая хроника как форма репрезентации культурной памяти. Вестник Московского государственного лингвистического университета. Гуманитарные науки, 10(803), 288-293.

\section{- References}

Assmann, J. (2004). Kul'turnaya pamyat'. Pis'mo, pamyat' o proshlom i politicheskaya identichnost' $v$ vysokikh kul'turakh drevnosti [Cultural memory. Writing, memory of the past and political identity in the high cultures of antiquity] (M. M. Sokol'skaya, Trans.). Yazyki slavyanskoi kul'tury [in Russian]. 
Ciceronis, M. T. (1972). Tri traktata ob oratorskom iskusstve [Three treatises on oratory] (F. A. Petrovskii, Trans., Vol. 2). Nauka [in Russian].

Evlampiev, I. I. (2016). Ideya muzeya $v$ kontekste evropeiskoi modeli kul'tury i ee postmodernistskoe otritsanie [The idea of museum in the context of european model of culture and its postmodern denial]. International journal of cultural research, 3(24). http://www.intelros.ru/pdf/Int_culture_researsh_mag/2016_03/ijcr_3-24-2016_ evlampiev\%20103-114.pdf [in Russian].

Gurevich, A. (1990). Srednevekovyi mir: kul'tura bezmolvstvuyushchego bol'shinstva [Medieval world: the culture of the silent majority]. Iskusstvo [in Russian].

Haidai, O. (2018). Kamianyi hist. Lenin u tsentri Ukrainy [Stone guest. Lenin in the center of Ukraine] (2nd ed.). K.I.S. [in Ukrainian].

Holyk, R. (2017, August 14). Pamiat kultury na rozdorizhzhiakh nauky: problemy teorii [Memory of culture at the crossroads of science: problems of theory]. Ukraina moderna. https:// uamoderna.com/demontazh-pamyati/holyk-collective-memory [in Ukrainian].

Kravchenko, O. (2019). Kulturni transformatsii mista u postindustrialnu dobu [Cultural transformations of the city in the post-industrial age] [PhD Dissertation, National Aviation University] [in Ukrainian].

Quintilianus, M. F. (1834). Dvenadtsat' knig ritoricheskikh nastavlenii [Twelve books of rhetorical instruction] (A. Nikol'skii, Trans., Pt. 1). Imperatorskaya Rossiiskaya Akademiya. http://ancientrome.ru/antlitr/t.htm?a=1295581698 [in Russian].

Ragozina, T. (2017). Kul'turnaya pamyat' versus istoricheskaya pamyat' [Cultural memory versus historical memory]. Science. Arts. Culture, 3(15), 12-21 [in Russian].

Shipilov, S. (2018). Srednevekovaya khronika kak forma reprezentatsii kul'turnoi pamyati [Medieval Chronicle as a form of representation of cultural memory]. Vestnik Of Moscow State Linguistic University. Humanities, 10(803), 288-293 [in Russian].

Svyatoslavs'kii, A. (2011). Sreda obitaniya kak sreda pamyati: $k$ istorii otechestvennoi memorial'noi kul'tury [Habitat as a memory environment: on the history of Russian memorial culture] [Abstract of DSc Dissertation, Moscow Pedagogical State University] [in Russian].

Tolkacheva, V. (2019). Transformatsiya soderzhaniya kul'turnoi pamyati v virtual'nom prostranstve [Transformation of the content of cultural memory in the virtual space] [Abstract of PhD Dissertation, National Research Tomsk Polytechnic University] [in Russian].

Vakhshtain, V. (2018). Kollektivnaya pamyat' kak resurs kontseptualizatsii publichnykh $i$ privatnykh prostranstv $v$ megapolise [Collective memory as a resource for conceptualising public and private spaces in a metropolis]. Retrieved April 9, 2020, from https://cutt.ly/YhzsDRs [in Russian].

Verbytska, P. (2018). Kulturna pamiat yak chynnyk konstruiuvannia identychnosti v umovakh transformatsii ukrainskoho suspilstva [Cultural memory as a factor of identity construction in the conditions of Ukrainian society transformation]. Historical and Cultural Studies, 5(1). http://science.Ipnu.ua/sites/default/files/journal-paper/2019/ apr/16428/5.pdf [in Ukrainian]. 


\section{- CULTURAL MEMORY OF CITIES}

\section{- Maryna Otrishko}

- External PhD student, ORCID: 0000-0001-7944-5085, e-mail: m_14@ukr.net, Kyiv National University of Culture and Arts, Kyiv, Ukraine

\section{- Abstract}

The purpose of the article is to present an argument for the equal importance of cultural memory as a value in the cultural advancement of the cities. The research methodology is based on the use of the following methods: search, comparison, analysis and synthesis, which revealed the transformation of the interpretation of cultural memory at different times. The work has high scientific novelty since it allows for the first time to analyse the evolution of the public understanding of the concept of "cultural memory". It has been proven that "memory", "art of memory" and "cultural memory" are the objects of interest in each of the cultural epochs. Ancient thinkers are the pioneers for the culture of memory term. However, the concept of "cultural memory" appears in scientific use only in the late $20^{\text {th }}$ century in the research by $\mathrm{J}$. Assmann. Cultural memory is understood as the sphere of existence; space in combination with cultural infrastructure; environment for preserving the system of cultural values that are available in public space. Conclusions. It was found that cultural memory has a significant impact on building the identity of both citizens and the city. By preserving and "reading" cultural memory in the city, there is a connection between society and the past, awareness of values, patterns of public behaviour in different historical periods. It is argued that cultural memory is an integral part of urban space. Being a "dialogue" between the past and the present, cultural memory reflects the values of society through the "cultural patterns of the city". The most meaningful cultural memory is manifested in the culture of memorialisation: monuments, memorial complexes, memorial buildings, inscriptions, demonstrating the ideological features of a particular historical period. However, the process of globalisation has a negative impact on cultural memory in the city, leading to assimilation of cultural values. The emphasis on the preservation, increase, and promotion of cultural monuments in cities is significant. It will contribute to the understanding of their own identity and the improvement of socio-cultural development of territories.

Keywords: memory; cultural memory; art of memory; public space; city 


\section{- КУЛЬТУРНАЯ ПАМЯТЬ ГОРОДОВ}

\section{- Отришко Марина Анатольевна}

- Соискатель, ORCID: 0000-0001-7944-5085, e-mail:m_14@ukr.net, Киевский национальный университет культуры и искусств, Киев, Украина

\section{- Аннотация}

Цель статьи - обоснование значимости культурной памяти как фактора культурного развития городов. Методология исследования основана на использовании следующих методов: поисковый, сравнительный, анализ и синтез, что позволило выявить трансформацию толкования культурной памяти в разных временных промежутках. Научная новизна работы заключается в том, что в ней впервые проанализирована эволюция понимания общественностью понятия «культурная память». В статье доказано, что «память», «искусство памяти», «культурная память» являются объектом интереса в каждой из культурных эпох. Античные мыслители являются первооткрывателями культуры памяти. Однако, понятие «культурная память» появляется в научном обороте лишь в конце XXв. в исследованиях Я. Ассмана. Под культурной памятью понимают сфреру бытия; пространство в сочетании с культурной инфраструктурой; среду сохранения системы культурных ценностей, что имеются в публичном пространстве. Выводы. Выявлено, что культурная память имеет существенное влияние на построение идентичности и горожан, и города. Благодаря сохранению и «прочтению» культурной памяти в пространстве города, происходит связь общества с прошлым, осознание ценностей, моделей поведения общественности в различных исторических периодах. Обосновано, что культурная память является неотъемлемой составляющей городского пространства. Играя роль «диалога» между прошлым и настоящим, культурная память отражает ценности общества с помощью «культурного кода города». Наиболее содержательно культурная память проявляется в культуре мемориализации: памятниках, мемориальных комплексах, памятных сооружениях, надписях, демонстрируя мировоззренческие особенности определенного исторического периода. Однако, процесс глобализации оказывает негативное влияние на культурную память в городе, вызывая ассимиляцию культурных ценностей. Акцентирование на сохранении, приумножении и продвижении объектов культурной памяти в городах является значимым и будет способствовать осмыслению собственной идентичности и совершенствованию социокультурного развития территорий.

- Ключевые слова: память; культурная память; искусство памяти; публичное пространство; город 